\title{
TIME - MORTALITY RELATIONSHIPS FOR THE LIFE STAGES OF RED FLOUR BEETLE, TRIBOLIUM CASTANEUM EXPOSED TO HIGH AND LOW TEMPERATURES, AND THEIR RELATION WITH FLOUR TECHNOLOGY
}

\author{
SANAA, M. M. ${ }^{1}$, M. M. ZEWAR ${ }^{1}$, SALWA, M. A ${ }^{1}$ and SEHAM, Y. GEBREIL ${ }^{2}$. \\ 1- Plant Protection Research Institute, Agricultural Research Center, Dokki, Giza, Egypt. \\ 2- Food Technology Research Institute (FTRI).
}

(Manuscript received 8 November 2017)

\begin{abstract}
$\mathrm{T}$ emperature treatments of stored grains and grain products is the best physical method which successfully kills several life stages of insects. Survival of adults, pupae, younger larvae and older larvae of Tribolium castaneum exposed to 40, 50, $60,-5$ and $-10^{\circ} \mathrm{C}$ at different exposure periods $(15,20,25,30,40$, $45,60,90$ and $120 \mathrm{~min}$ ) were investigated. Probit analysis was used to determine the lethal time required for 50 and $95 \%$ kill ( $L T_{50}$ and $L T_{95}$ ) of the population of tested insect, results indicated that: Younger and older larvae were the most heat susceptible stages with $\mathrm{LT}_{50}$ and $\mathrm{LT}_{95}$ as compared the pupae and adult stages at the higher temp. $\left(60^{\circ} \mathrm{C}\right)$. Pupae and adult stages were the most heat tolerant stage at $60{ }^{\circ} \mathrm{C}$. Exposing the beetles to $60^{\circ} \mathrm{C}$ and -10 ${ }^{\circ} \mathrm{C}$ resulted a higher mortality than for beetles that were maintained at two previous tested temperature. The cold tolerance of different stages from lower to highest at -5 and $-10{ }^{\circ} \mathrm{C}$ were older larvae < younger larvae < adult < pupae. Grain Technology studied were carried out on samples of wheat flour exposed to 60 ${ }^{\circ} \mathrm{C}$ for $120 \mathrm{~min}$. and to $-10{ }^{\circ} \mathrm{C}$ for $90 \mathrm{~min}$. to determined chemical composition, Rheological properties and organoleptic characteristics of balady bread. Results indicated that, No significant differences were observed between treated samples and untreated control. Finally, it could be concluded that, the influence of both heat or cold treatments on the mortality rate of tested insect was positively correlated with the time of exposure, the increase of heat or cold temperature and the stage of insect.
\end{abstract}

\section{INTRODUCTION}

There is a continuous need to protect the stored products against deterioration, especially loss of quality and weight during storage mainly due to insects. Flour mill can be infested by a variety of beetles. Among them, Tribolium castaneum Herbst is one of the most wide spread and destractive pests of stored products, feeding on different stored grain and grain products (Weston and Rattlingourd, 2000; Mishra et al. ,2012).

Conventional chemicals, either grain protectants or fumigants have been or may be restricted globally for use in the control of stored products insects because of problems related to the persistence of toxic residues in food grains, the development 
of insect resistance and adverse environmental impact. Thus, ecologically safe methods to control insect of stored food products have been extensively investigated. Fortunatly, insects are sensitive to temperatures changes within their environment, therefore, the use of extreme temperature to restrict pest population is an ideal tool for organic food industry. The lethal temperature zones for insects are those above or below the suboptimum which will eventually kill the organism. Susceptibility of insects to lethal temperature varies greatly between species and life stages and it often dependent upon factors such as temperatures, length of exposure time, sex and ambient air relative humidity (Ferizli et al. , 2004). Most of the stored product insects cannot tolerate extreme temperatures, heating or cooling and show heavy mortality. Super heating of food grains provide extra protection without treating with any insecticides (Upodhyay and Ahmed 2011).

The present study was designed to identify the most tolerant stage of $T$. castaneum for high and low temperatures and different temperature - exposure time needed to kill the various stages of insects in flour mill.

On the other hand, the effect of temperature treatments on a chemical analysis, rheological properties, determination of gluten of flour mill were studied also, balady bread making and sensory evaluation of bread loaves.

\section{MATERIALS AND METHODS}

Insect culture: Cultures of red flour beetle, Tribolium castaneum (Hbst) were reared on $250 \mathrm{~g}$ wheat flour inside glass jar (each $0.5 \mathrm{~kg}$. capacity) and infested with 500 adults. Jars were closed with filter paper lids until the emergency at $28{ }^{\circ} \mathrm{C}$ and $65 \pm$ $5 \% \mathrm{RH}$. Cultures were sieved weekly till the end of experiments.

Prepared the tested stages: To obtain larval stage, 500 newly emerged adults were introduced in plastic containers ( $1 \mathrm{~kg}$ capacity) holding $500 \mathrm{gm}$ of flour that was sifted through a $250 \mu \mathrm{m}$ sieve to obtain eggs. Deposited eggs were incubated at 28 ${ }^{\circ} \mathrm{C}$ and $65 \pm 5 \% \mathrm{RH}$. , left up to hatched. The flour were divided to four groups (100 larvae/ group). Every group i.e 100 larvae were introduced in plastic container holding $50 \mathrm{gm}$ of the flour and left for 6 days; 20 day; 25-30 days to obtain younger larvae, older larvae and pupal stage respectively. The final group lift until emergence of adults.

Pupae (one- day old) and adults ( 2- wk- old ) were used in the experiments. Untreated control containers were also prepared for each stage. 
The exposure to tested temperature: Young and old larvae, older larvae, pupal and adult stages were introduced in $30 \mathrm{ml}$ glass vials on ( $10 \mathrm{~g}$ ) flour. The stages were exposed to $40,50,60,-5$ and $-10^{\circ} \mathrm{C}$ degree at different exposure time i.e 15 , 20, 25, 40, 45, 60, 90 and 120 minute.

All experiments as well as the untreated control were kept in rearing room at $28{ }^{\circ} \mathrm{C}$ and $65 \pm 5 \% \mathrm{RH}$. and replicated for three times.

- Insect mortality assessment: After 24 hours of heat and cold treatments, the number of live and dead larvae, pupae and adults was determined. Percentage of mortality in immature stages (young and old larvae) was calculated based on number of individuals that did not transfered to pupae stage.

Pupal stage was held until adult emergence. Mortality account was based on those that failed to emerge while the number of dead adult was detected for adult stage.

All bioassay were brought to laboratory and incubated at $28^{\circ} \mathrm{C}$ and $65 \pm 5 \% \mathrm{RH}$.

Grain Technology properties: All experiments were carried out on wheat flour exposed to $60^{\circ} \mathrm{C}$ for $90 \mathrm{~min}$. and $-10^{\circ} \mathrm{C}$ for $60 \mathrm{~min}$.

Chemical analysis: Moisture, crude protein, lipids, crude fiber and ash contents were determined according to the methods of AOAC (2005). Total hydrolysable carbohydrates were calculated by difference.

- Rheological properties: The rheological properties of different wheat flour doughs were tested by farinograph according to the methods described in AACC (2002).

- Determination of gluten: The wet and dry gluten were determined according to the method of AACC (2002).

- Balady bread making: Balady bread was prepared according to the method described by Faridi and Rubenthaler (1984).

- Sensory evaluation of bread loaves: Balady bread loaves were organo leptically evaluated for general appearance (20), roundness (10), crust color (10), separation of layers (10), distribution of crumb (10), odor (20) and taste (20). The evaluation was carried out by ten trained panelists from Food Technology Research Institute (FTRI). The quality scores of the evaluated bread loaves were performed as reported by EL- Farra et al. (1982).

\section{- Statistical analysis}

Mortality of $T$. castaneum stage was corrected for mortality in corresponding control treatments (Abbot 1925). The corrected mortality data for tested stages were calculated.

Computed percentage of mortality was plotted versus the corresponding concentrations using LD $\mathrm{p}$ line software program to obtain the toxicity regression lines. The lethal concentrations $\mathrm{LC}_{50}$ and $\mathrm{LC}_{95}$ were determined. 


\section{RESULTS AND DISCUSSION}

\section{1- Survival of different development stages at high temperature:}

Pupae and adults stages were the most heat tolerant stages with LT 50 of 89.62 and $69.09 \mathrm{~min}$. resp. at $40^{\circ} \mathrm{C}$ followed by younger and older larvae (Table 1). Lethal time ( $\left(\mathrm{T}_{95}\right)$ required to kill the pupae and adults was investigated at tested temperatures.

LT95 values were $150.84,128.65$ and $97.71 \mathrm{~min}$. at 40,50 and $60{ }^{\circ} \mathrm{C}$ resp. for pupal stage, meanwhile, it was $128.63,106.8$, `and 91.89 min at tested temp. for adult stages (Table 1 ). These results agreed previous research which has shown that the susceptibility of stored product insects to heat varied among species and within a species among the life stages (Mahroof et al. , 2003a).

Younger and older stages were the most heat susceptible stages with LT50 of 60.51 and $44.69 \mathrm{~min}$. at $40{ }^{\circ} \mathrm{C}$ the susceptibility was increased at $60 \circ \mathrm{C}$ which gave 37.82 and 30.71 min., meanwhile, $50^{\circ} \mathrm{C}$ gave intermediate values at LT 50.

Results in (Table 1) indicated also that LT95 of younger and older larvae decreased by increasing the temperature, it reach 51.25 and $47.2 \mathrm{~min}$. resp. at $60{ }^{\circ} \mathrm{C}$. Exposing the larvae to $60{ }^{\circ} \mathrm{C}$ resulted a greater mortality than prolonged maintenance at $40^{\circ} \mathrm{C}$.

In mentioned before, the tested larvae of $T$. castaneum seemed to be more susceptible as compared the pupae and adult stages. These results agreed with upadhyay and Ahmed (2011) who proved that, super heating of grains provide extra protection without treating with any insecticides. and proved that it can kill all life stages of stored grain pests in werehouse by extreme temperatures.

\section{2- Survival of different stages of $\boldsymbol{T}$. castaneum at cold temperatures :} Table (2) indicated that, pupal stage was the most cold - tolerant with LT 50 of 41.01 and 33.53 min. at -5 and -10 rasp. , meanwhile, adult stage gave a tolerant values to cold temp. but less than pupae with LT 50 of 35.94 and 26.33 min. and with LT 95 of 84.43 and $61.57 \mathrm{~min}$. at -5 and $-10^{\circ} \mathrm{C}$.

Older larvae showed the most susceptible degree at two previous cold temp. LT50 gave 23.06 and 16.90 at -5 and $-10{ }^{\circ} \mathrm{C}$. and gave 40.40 and 27.0 min. at LT 95 in older larvae resp. Table 2 showed also that younger larvae gave a degree of susceptible but less than older larvae.

Finally, the cold tolerance of different stages from lower to highest at -5 and -10 ${ }^{\circ} \mathrm{C}$ were older larvae < younger larvae < adult < pupae.

Reviewing the obtained results, it could be conducted that, the influence of both dry heat and cold treatments on the mortality rate of tested insect was positively correlated with the time of exposure, the increase of both heat and cold temp. and the stage of tested insect. 
In a general trend, larvae stages proved more susceptible to both heat and cold treatments when compared with pupae and adult stages. These results agree with Eliopouls et al (2010) and Alder ( 2000).

Chemical composition of wheat flour samples : Results in Table (3) showed the chemical composition, i. e. , protein , moisture, ash, fat, fiber and total carbohydrates of wheat flour samples.

From results, heat treatment recorded the highest moisture value followed by control then cold treatment, these results due to treatments.

No significant differences were observed between all samples in ash, protein and fat values. They ranged from 0.88 to $0.90 \%, 11.25$ to $11.50 \%$ and 1.85 to $1.88 \%$ resp.

Concerning fiber, cold treatment recorded slightly decrease compared with control and heat treatment $(0.86 \%)$. Carbohydrates value showed insignificant differences between control and other samples.

\section{Rheological properties of wheat flour dough}

Rheological properties were measured by farinograph parameters and gluten content as presented in Table ( 4 ).

\section{a- Farinograph parameters:}

Wheat flour doughs were rheologically tested by using farinogragh for water absorption ( $\%$ ), arrival time (min. ), dough development ( min. ), dough stability ( min. ) and degree of softening ( or dough weakening ) ( B. U. ).

Results in Table ( 4 ) and Fig. ( 1 ) showed that heat treatment recorded the highest values of water absorption and dough stability ( $61.5 \%$ and $12.5 \mathrm{~min}$. , resp. ) followed with cold treatment then control.

Degree of softening recorded the same value in all samples ( 40 B. U. ).

Regarding gluten values, it was found that dry gluten increased in heat and cold treatments compared with control, but gluten index decreased compared with control Table ( 4 ) and Fig.( 1 )

Oraganoleptic characteristics of balady bread : Sensory evaluation of balady bread leaves produced from treated wheat flour, i. e. , general appearance, roundness, crust color, separation of layers, distribution of crumb, odor and taste are presented in Table ( 5 ) and Fig. ( 2 )

Results in Table ( 5 ) indicated that values of general appearance, roundness and crust color increased gradually from control to heat and cold samples, but the other parameters decreased. Odor and taste ranged from 19.00 to 19.33, resp.

Generally, no significant differences were observed between control and the other samples in all organoleptic characteristics. 
Table 1 . Lethal time to kill 50 and $95 \%$ of the population of various life stages of the T. castaneum exposed to different constant high temperatures.

\begin{tabular}{|c|c|c|c|c|}
\hline \multirow[t]{2}{*}{ Stage } & \multicolumn{3}{|c|}{$40^{\circ} \mathrm{C}$} & \multirow{2}{*}{$\begin{array}{r}\text { Probability } \\
\text { ( P.) }\end{array}$} \\
\hline & $\mathrm{LT}_{50}$ ( min. ) & $\mathrm{LT}_{95}$ ( min. ) & Slope \pm SE & \\
\hline Younger larvae & 60.51 & 118.99 & $2.69 \pm 0.34$ & 0.15 \\
\hline Older larvae & 44.69 & 91.01 & $2.93 \pm 0.28$ & 0.84 \\
\hline Pupae & 89.62 & 150.84 & $2.10 \pm 0.40$ & 0.61 \\
\hline Adults & 69.09 & 128.63 & $3.02 \pm 0.48$ & 0.18 \\
\hline \multicolumn{5}{|c|}{$50^{\circ} \mathrm{C}$} \\
\hline Younger larvae & 41.83 & 85.11 & $3.05 \pm 0.3$ & 0.96 \\
\hline Older larvae & 40.79 & 63.35 & $3.40 \pm 11.1$ & 0.18 \\
\hline Pupae & 88.11 & 128.65 & $4.38 \pm 0.6$ & 0.11 \\
\hline Adults & 51.02 & 106.80 & $4.34 \pm 0.5$ & 0.002 \\
\hline \multicolumn{5}{|c|}{$60^{\circ} \mathrm{C}$} \\
\hline Younger larvae & 37.82 & 51.25 & $3.95 \pm 0.36$ & 0.0006 \\
\hline Older larvae & 30.71 & 47.2 & $3.97 \pm 0.37$ & 0.02 \\
\hline Pupae & 43.48 & 97.71 & $4.43 \pm 0.31$ & 0.0 \\
\hline Adults & 42.26 & 91.89 & $2.81 \pm 0.44$ & 0.62 \\
\hline
\end{tabular}

Table 2 . Lethal time to kill 50 and $95 \%$ of the population of various life stages of $T$. castaneum exposed to -5 and $-10^{\circ} \mathrm{C}$ :

\begin{tabular}{|c|c|c|c|c|}
\hline \multirow[t]{2}{*}{ Stage } & \multicolumn{3}{|c|}{$-5^{\circ} \mathrm{C}$} & \multirow{2}{*}{$\begin{array}{r}\text { Probability } \\
\text { (P.) }\end{array}$} \\
\hline & LT 50 (min. ) & LT 95 ( min. ) & Slope \pm SE & \\
\hline Younger larvae & 30.03 & 45.78 & $3.14 \pm 0.26$ & 0.0 \\
\hline Older larvae & 23.06 & 40.40 & $2.55 \pm 0.21$ & 0.10 \\
\hline Pupae & 41.01 & 89.32 & $2.17 \pm 0.19$ & 0.12 \\
\hline Adults & 35.94 & 84.43 & $2.26 \pm 0.19$ & 0.09 \\
\hline \multicolumn{5}{|c|}{$-10^{\circ} \mathrm{C}$} \\
\hline Younger larvae & 20.26 & 58.90 & $2.46 \pm 0.27$ & 0.12 \\
\hline Older larvae & 16.90 & 27.00 & $3.38 \pm 0.31$ & 0.56 \\
\hline Pupae & 33.53 & 66.16 & $2.95 \pm 0.38$ & 0.22 \\
\hline Adults & 26.33 & 61.57 & $4.52 \pm 0.4$ & 0.00 \\
\hline
\end{tabular}

Table 3 . Chemical composition of wheat flour samples ( $\%$ on dry weight ).

\begin{tabular}{|c|c|c|c|c|c|c|}
\hline Treatment & Moisture & Protein & Crude fiber & Fat & Ash & $\begin{array}{c}\text { Total } \\
\text { carbohydrates }\end{array}$ \\
\hline Control & $12.86 \pm$ & $11.37 \pm$ & $1.00 \pm$ & $1.88 \pm$ & $0.88 \pm$ & $84.88 \pm$ \\
& $0.0565^{\mathrm{a}}$ & $0.1626^{\mathrm{a}}$ & $0.0565^{\mathrm{a}}$ & $0.282^{\mathrm{a}}$ & $0.0141^{\mathrm{a}}$ & $0.1484^{\mathrm{a}}$ \\
\hline Heat sample & $13.04 \pm$ & $11.50 \pm$ & $1.01 \pm$ & $1.85 \pm$ & $0.90 \pm$ & $84.75 \pm$ \\
& $0.1343^{\mathrm{a}}$ & $0.1626^{\mathrm{a}}$ & $0.0353^{\mathrm{a}}$ & $0.0282^{\mathrm{a}}$ & $0.0141^{\mathrm{a}}$ & $0.2121^{\mathrm{a}}$ \\
\hline Cold sample & $10.68 \pm$ & $11.25 \pm$ & $0.86 \pm$ & $1.86 \pm$ & $0.88 \pm$ & $85.16 \pm$ \\
& $0.2191^{\mathrm{b}}$ & $0.0848^{\mathrm{a}}$ & $0.0282^{\mathrm{b}}$ & $0.0212^{\mathrm{a}}$ & $0.0494^{\mathrm{a}}$ & $0.1272^{\mathrm{a}}$ \\
\hline L.S.D & 0.4836 & 0.4504 & 0.1331 & 0.0831 & $0.0984 \mathrm{a}$ & 0.5301 \\
\hline
\end{tabular}
Mean $(n=3) \pm S D$ in the same coloum with different superscripted letters are significantly different $(p \leq 0.05)$.

Table 4 . Farinograph parameters and gluten values of wheat flour dough samples

\begin{tabular}{|c|c|c|c|c|c|c|c|c|}
\hline Treatment & \multicolumn{4}{|c|}{ Farinograph parameters } & \multicolumn{3}{|c|}{ Gluten values } \\
\cline { 2 - 9 } & $\begin{array}{c}\text { Water } \\
\text { absorption } \\
(\%)\end{array}$ & $\begin{array}{c}\text { Arrival } \\
\text { time } \\
(\mathrm{min})\end{array}$ & $\begin{array}{c}\text { Dough } \\
\text { development } \\
(\mathrm{min})\end{array}$ & $\begin{array}{c}\text { Dough } \\
\text { stability } \\
(\mathrm{min})\end{array}$ & $\begin{array}{c}\text { Degree } \\
\text { of } \\
\text { softening } \\
(\mathrm{B} . \mathrm{U})\end{array}$ & $\begin{array}{c}\text { Wet } \\
\text { gluten } \\
(\%)\end{array}$ & $\begin{array}{c}\text { Dry } \\
\text { gluten } \\
(\%)\end{array}$ & $\begin{array}{c}\text { Gluten } \\
\text { Index }\end{array}$ \\
\hline Control & 57.0 & 1.0 & 1.5 & 11.0 & 40 & 17.96 & 4.25 & 97.27 \\
\hline Heat sample & 61.5 & 1.0 & 1.5 & 12.5 & 40 & 20.86 & 5.48 & 95.61 \\
\hline Cold sample & 59.0 & 2.0 & 2.5 & 12.0 & 40 & 21.64 & 5.59 & 94.52 \\
\hline
\end{tabular}

B. U Brabender unit. 
Table 5. Sensory evaluation of produced bread from wheat flour samples.

\begin{tabular}{|c|c|c|c|c|c|c|c|}
\hline Treatment & $\begin{array}{c}\text { General } \\
\text { appearance } \\
\text { (20) }\end{array}$ & $\begin{array}{l}\text { Roundness } \\
\qquad(10)\end{array}$ & $\begin{array}{l}\text { Crust color } \\
\qquad(10)\end{array}$ & $\begin{array}{l}\text { Separation of } \\
\text { layers ( } 10)\end{array}$ & $\begin{array}{l}\text { Distribution of } \\
\text { crumb ( } 10 \text { ) }\end{array}$ & $\begin{array}{l}\text { Odor } \\
(20)\end{array}$ & $\begin{array}{l}\text { Taste } \\
(20)\end{array}$ \\
\hline Control & $18.77 \pm 0.8700^{a}$ & $9.66 \pm 0.5000^{a}$ & $9.16 \pm 0.6614^{a}$ & $9.88 \pm 0.3333^{a}$ & $9.77 \pm 0.4409^{a}$ & $19.66 \pm 0.7071^{a}$ & $19.33 \pm 0.8660^{\mathrm{a}}$ \\
\hline Heat sample & $18.94 \pm 1.0736^{a}$ & $9.66 \pm 0.7071^{a}$ & $9.33 \pm 0.8660^{\mathrm{a}}$ & $9.44 \pm 1.1303^{\mathrm{a}}$ & $9.00 \pm 1.3228^{a}$ & $19.05 \pm 1.1303^{a}$ & $19.16 \pm 1.0606^{\mathrm{a}}$ \\
\hline Cold sample & $19.11 \pm 0.7817^{a}$ & $9.77 \pm 0.4409^{a}$ & $9.38 \pm 0.4859^{a}$ & $9.55 \pm 1.0137^{a}$ & $9.00 \pm 0.8660^{\mathrm{a}}$ & $19.00 \pm 1.0307^{a}$ & $19.00 \pm 0.9682^{\mathrm{a}}$ \\
\hline L.S.D & 0.8916 & 0.5458 & 0.6702 & 0.8732 & 0.9220 & 0.9466 & 0.9420 \\
\hline
\end{tabular}

Mean $(n=10) \pm S D$ in the same coloum with different superscripted letters are significantly different $(P \leq 0.05)$. 

TRIBOLIUM CASTANEUM EXPOSED TO HIGH AND LOW TEMPERATURES, AND THEIR RELATION WITH FLOUR TECHNOLOGY

\section{(a )}

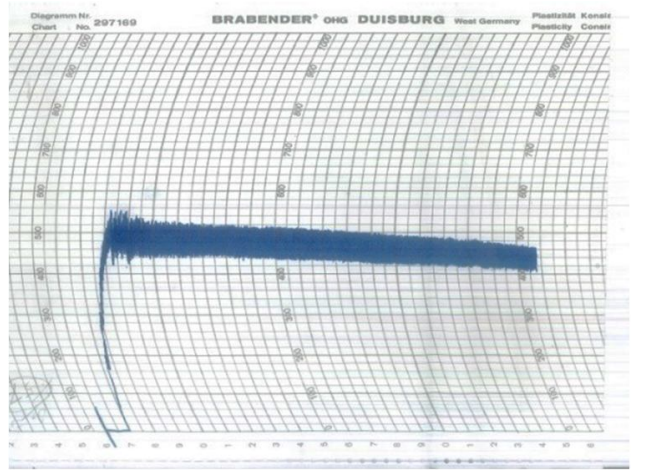

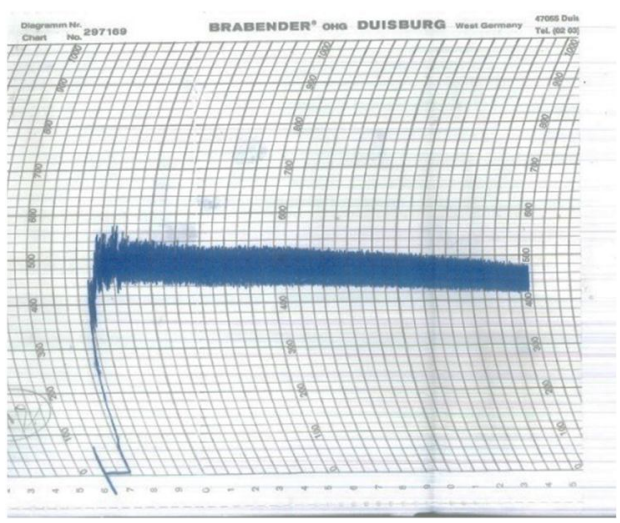

(b)

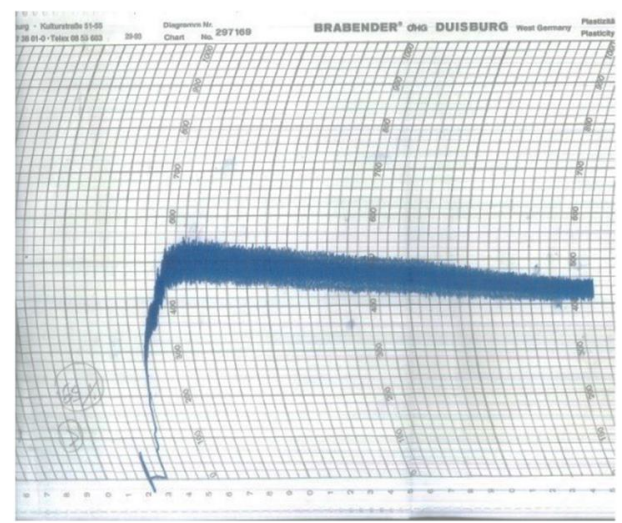

(c)

Fig. 1 . Farinogram curves of wheat flours dough samples.

( a ) Control sample.

(b) Heat sample.

(c) Cold sample. 


\section{(a )}

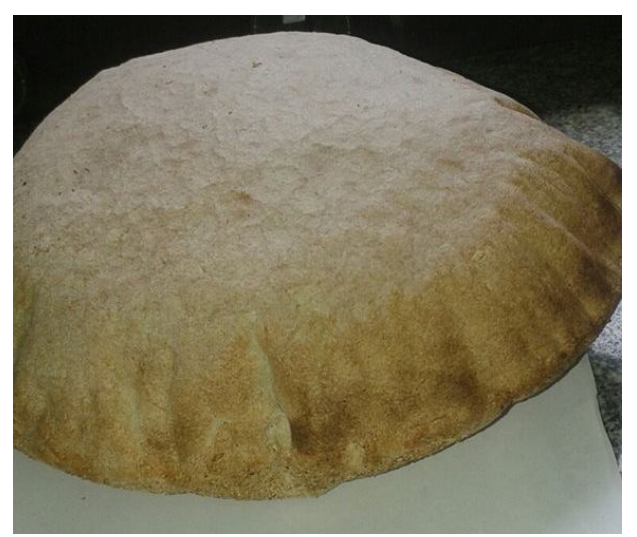

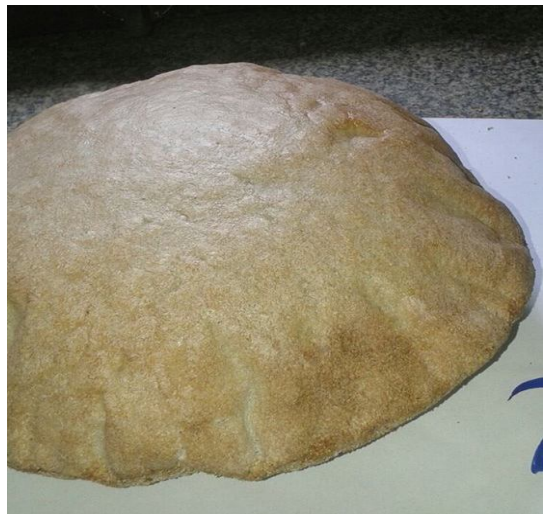

( b )

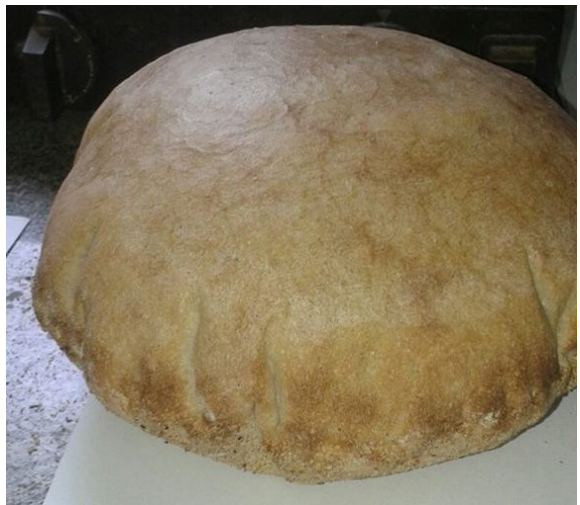

(c)

Fig. 2 . balady bread produced from wheat flour dough sample

( a ) Control sample.

(b) Heat Sample.

(c) Cold Sample. 


\section{REFERENCES}

1. A. C. C. 2002. Approved Methods of the American Association of Cereal Chemists, St Paul Minnesota. American Association of Cereal Chemists.

2. Abbott, W. S. 1925. A method of the effectiveness of an insecticide. J. Econ. Entomol; 18; 265 - 270.

3. Alder, C. Rassamann, W. 2000. Utilisation of extreme temps. in stored product protection. proceeding of the meeting of IOBC - WPRS, Berlin, 22 - 24 Augast 1999, IOBC Bulletin 23 (10), 257 - 262.

4. Anon Y Mous. 2012. General Managements of Agricultural statistics, Economic Affairs Sector, Ministry of Agriculture, Egypt.

5. AOAC 2005. Official Methods of Analysis of Association of official Analytical Chemists International. $18^{\text {th }}$ Ed., Maryland, DC.

6. Belderok, B. 2000. Developments in bread - making processes. Plant Foods and human nutrition, 55: 1 - 4.

7. El-Farra, A. A.; A. M. Khorshid; S. M. Mansour and A. M. Galal. 1982. Studies on the possibility of supplementation of balady bread with various commercial soy products. Egypt. Conf. on Bread Res.

8. Eliopoulos, P. A, Prasodimous, G. Z. ,Pouliou A. V. 2010. Survival of adults and larvae of grain beetles at lethal low temperature. $10^{\text {th }}$ International Working Conference on stored product protection, Greece.

9. Faridi, H. A. and G. L. Rubenthaler. 1984. Effect of baking time and temperature on bread quality, starch gelatinization, and staling of egyptian balady bread. Cereal Chem. 61(2): 151-154.

10. Farizli, A. G. , M. Emekci, S. Tutuncu and S. Navarro. 2004. Utilization of freezing temp. to control C. maculatus Integrated Protection of Stored product, IOBC, Bulletin. Wprs vol. 27 (9).

11. Mahroof, R. Subramanyam, B. H. 2003. Temperature and relative humidity profiles during heat treatment of mills and its efficacy against T.castaneum life stages. J. Stored prod. Res, 39: 555 - 569.

12. Mishra, B. B. Tripathi, S. P. Tripathi C. P. M. 2012. Response of T. castaneum and Sitophilus oryzae to potential insecticide derived from essential oil of Mentha arvensis Leaves - Biological Agri and Horticulture 28: 34- 40.

13. Slavin, J. L. 2000. Whole grains refined grains and fortified refined grains: Whats the difference? Asia Pacific. J. Clin. Nutr. , 9: 23 - 27.

14. Upadhyay, R. K. and S. Ahmed. 2011. Management stratigies for control of stored grain insect pests in farmer stores and public ware houses. World J. of Agric. Sciences 7 (5 ) 527 - 549.

15. Weston P. A. ,Rattlingourd P. A. 2000. Progeny production by T. castaneum and O surinamensis on maize previously infested by Sitotroga cerelella. J. econ. Ent. 93: $533-535$ 
العلاقه بين النسبه المئويه للموت والزمن على الأطوار المختلفة لحشرة خنفساء الاقيق الكستنائية لارجات الحرارة العالية والمنخفضة عند فترات زمنية مختلفة وتأثيرها على تكنولوجيا الدقيق

سناء محمود محجوب'، مواهب محمود زيور'، سلوى مصطفى أحمد'، سهام يحيى جبريل'

$$
\begin{aligned}
& 1 \text { - معهد بحوث وقاية النباتات - مركز البحوث الزراعية - دقى - جيزه - مصر . } \\
& \text { r- معهُ بحوث تكنولوجيا الأغذية. }
\end{aligned}
$$

تتاولت الدر اسة في هذا البحث استخدام درجات حرارة وبرودة لهذا الغرض، حيث تم استخدام

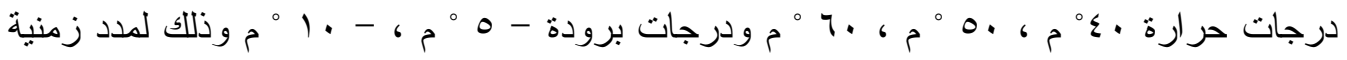

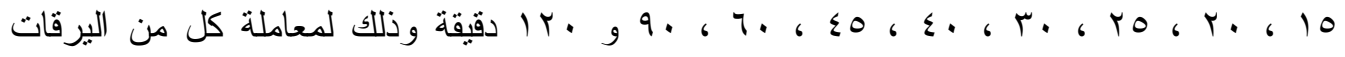

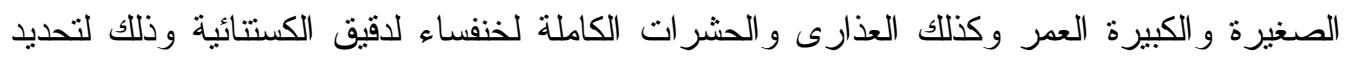
نسب الموت المختلفة نتيجة التعريض وكذللك تحديد الوقت النصفي المميت (LT50) وكذلك (LT95)

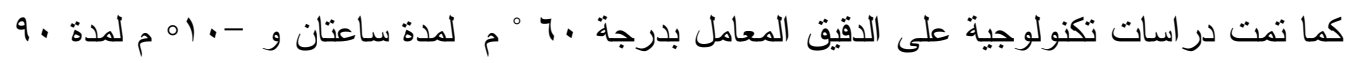

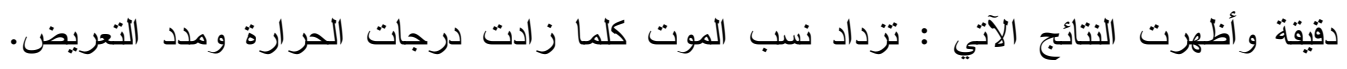
أظهرت الأعمار اليرقية المستخدمة حساسية كبيرة للتعرض للارجات الحرارية المستخدمة. أظهرت

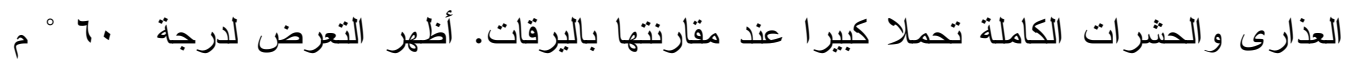
وكذلك - . 1 م م نسبا عالية من الموت إذا ما قورنت بالدرجات الأخرى. أختلفت الأطوار

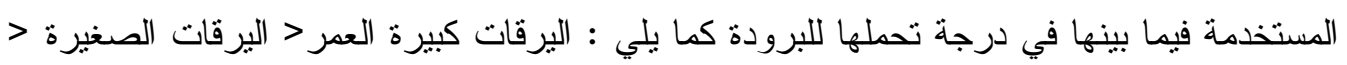
الحشرات الكاملة > العذارى.

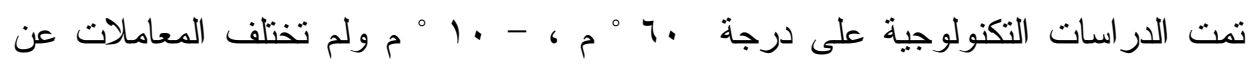

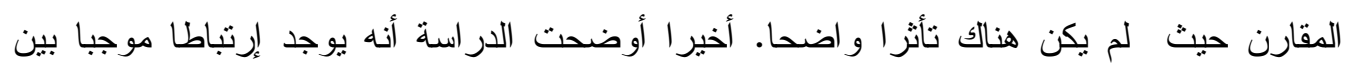

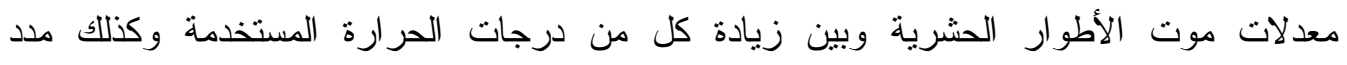

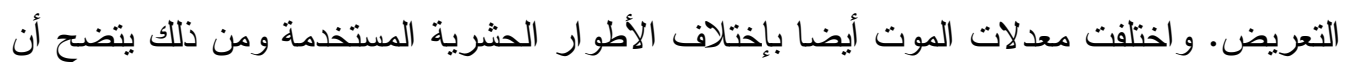
المعاملات الحرارية للحبوب والمنتجات المخزونة تعتبر من أفضل الطرق الفيزيقية المتبعة لقتل حشر ات الحبوب و المو اد المخزونة و أطوار ها وبالتالي الحفاظ على المنتجات سليمة. 
